\title{
Simple Additive Weigthing (SAW) Untuk Pemberian Reward Kepada Karyawan Pada PT. CAHAYA KASIH ANUGRAH
}

${ }^{1}$ Fernando B Siahaan, ${ }^{2}$ Shinta Listiana

${ }^{1}$ Universitas Bina Sarana Informatika, Indonesia

${ }^{2}$ STMIK Nusa Mandiri, Indonesia

Ifernando.fbs@bsi.ac.id; ${ }^{2}$ shintalistiana@gmail.com

\section{Article Info}

Article history:

Received, 27/10/2020

Revised, 3/11/2020

Accepted, 18/11/2020

\section{Kata Kunci:}

reward

sistem penunjang keputusan

simple additive weighting
Keywords:

reward

decision support system simple additive weigthing

\begin{abstract}
ABSTRAK
Reward adalah bentuk penghargaan yang diberikan perusahaan kepada karyawannya atas dedikasi, prestasi yang sudah ditunjukkan dalam satu periode tertentu, penghargaan ini sebagai bentuk timbal balik perusahaan kepada karyawan atas motivasi dan semangat dalam bekerja untuk kemajuan perusahaan. Reward ini diberikan agar setiap karyawan mampu menunjukkan prestasi kerja dalam persaingan positip menjadi yang terbaik pada tahun berikutnya.Permasalahannya belum ada sistem untuk melakukan penilaian karena masih bersifat manual, sistem penunjang keputusan diperlukan untuk menentukan penilaian kinerja karyawan berdasarkan kriteria-kriteria yang ditetapkan perusahaan. Simple additive weighting (SAW) metode terbaik untuk melakukan penjumlahan terbobot setiap alternatif pada atribut. Tujuan penelitian ini untuk mengetahui penilaian kriteria karyawan terbaik yang mendapatkan reward dengan menggunakan simple additive weighting. Pada pembahasan dijelaskan kriteria pada penilaian kinerja karyawan terdiri dari kopetensi, tanggung jawab, cara bersikap, kerjasama dan kedisipilnan. Kesimpulannya didapatkan karyawan terbaik saudara fredy setelah dilakukan penjumlahan nilai preferensi dari masing-masing pimpinan yaitu $1.46,1.53$ dan 1.58 dengan total 4.57, penilaian ini dengan mengikuti kriteria-kriteria yang ditetapkan perusahaan kepada seluruh karyawannya.
\end{abstract}

\section{ABSTRACT}

Reward is a form of appreciation given by the company to its employees for their dedication, achievements that have been shown in a certain period, this award is a form of company reciprocity to employees for their motivation and enthusiasm for working for the progress of the company. This reward is given so that each employee is able to show work performance in positive competition to be the best in the following year. The problem is that there is no system for conducting an assessment because it is still manual, a decision support system is needed to determine employee performance appraisal based on criteria set by the company. Simple additive weighting (SAW) is the best method for calculating the weighted addition of each alternative on the attributes. The purpose of this study was to determine the assessment of the criteria for the best employees who received rewards using simple additive weighting. In the discussion, it is explained that the criteria for evaluating employee performance consist of competence, responsibility, behavior, cooperation and discipline. The conclusion is that the best employees are Brother Fredy's after adding the preference values of each leader, namely $1.46,1.53$ and 1.58 with a total of 4.57 , this assessment follows the criteria set by the company for all its employees.

This is an open access article under the CC BY-SAlicense

\section{Penulis Korespondensi:}

Fernando B Siahaan,

Program Studi Sistem Informasi,

Universitas Bina Sarana Informatika,

Email: fernando.fbs@bsi.ac.id 


\section{PENDAHULUAN}

Sebuah perusahaan dikatakan akan maju apabila mempunyai sumber daya manusia unggul untuk mendukung proses bisnis perusahaan. Keunggulan Sumber daya ini sangat penting bagi perusahaan sehingga selain gaji sebagai hak karyawan, perusahaan juga perlu memberikan penghargaan kepada karyawannya dalam pemberian bonus. Prestasi kerja yang ditunjukkan karyawan bagi perusahaan akan mendapatkan reward dari perusahaan. Perusahaan menilai kinerja karyawan yang memuaskan dalam satu periode perlu diberikan penghargaan [1].

PT Cahaya Kasih Anugerah adalah sebuah perusahaan berkembang yang bergerak dibidang pengadaan barang. Pada setiap periode perusahaan selalu memberikan reward kepada karyawan sebagai motivasi kepada setiap karyawan untuk meningkatkan kinerjanya bagi perusahaan. Reward karyawan adalah penghargaan perusahaan kepada karyawan atas prestasi kerjanya, motivasi kerja perlu dihargai dalam bentuk hadiah sebagai semangat karyawan untuk memberikan prestasinya bagi perusahaan [2]. Karyawan adalah salah satu aset yang berguna sebagai penggerak dalam memajukan perusahaan, sehingga kinerja karyawan punya pengaruh terhadap kemajuan dan keuntungan yang didapat perusahaan tersebut [3].Setiap perusahaan akan memberikan reward kepada karyawan sebagai bentuk kompensasi dari kinerja yang diberikan karyawan kepada perusahaan, bentuk reward ini adalah sebagai penghargaan perusahaan kepada karyawan atas prestasi kerja yang dicapai dalam suatu periode [4]. Penilaian prestasi karyawan mutlak dilakukan oleh perusahaan untuk mengetahui prestasi yang telah dicapai karyawan dalam satu periode[5]. Namun didalam penentuan siapa karyawan terbaik perusahaan masih menemui kendala dikarenakan penilaian yang diberikan kepada karyawan masih bersifat subjektif[6].

Permasalahan pada pemilihan karyawan terbaik adalah dibutuhkan waktu yang lama ddialam melakukan seleksi karena belum adanya sistem standarisasi yang dimiliki perusahaan [7]. Diperlukan metode untuk menentukan karyawan terbaik sesuai kriteria yang ditetapkan sehingga hasil pemilihan karyawan terbaik ini akan memotivasi karyawan lain untuk menjadi yang terbaik pada periode berikutnya. Metode simple additive weighting sesuai digunakan pada penelitian ini dikarenakan mampu untuk menyeleksi alternatif terbaik dari sejumlah alternatif yang ada[8]. Metode saw adalah metode penjumlahan terbobot dari rating kinerja setiap alternatif semua atribut, untuk membuat matriks keputusan (x) diperlukan proses normalisasi dari semua alternatif [9].

Tujuan penelitian ini adalah untuk mengetahui penilaian kriteria karyawan terbaik yang mendapatkan reward dengan menggunakan simple additive weighting.

Sistem pendukung keputusan menentukan karyawan terbaik untuk pemberian reward memudahkan pengambil keputusan memilih karyawan terbaik berdasarkan kriteria perusahaan [10]. Sistem pendukung keputusan dapat membantu kepada user/pengguna untuk memberikan informasi yang tepat dalam memecahkan masalah yang berhubungan dengan kinerja karyawan dalam satu periode[11].

Tujuan dari sistem pengambilan keputusan[12] adalah

1) Mendukung Manajer pada pengambilan keputusan untuk masalah semi terstruktur[12]

2) Memberikan dukungan namun bukan menggantikan fungsi manager dalam pengambil keputusan[12].

3) Peningkatan efektivitas dalam pengambilan keputusan dari perbaikan efisiensi[12].

4) Kecepatan perhitungan komputer, memungkinkan manager untuk mendapatkan banyak alternatif dengan biaya yang rendah[12].

5) Meningkatnya produktivitas. Membangun kelompon pengambil keputusan terutama para pakar ternyata sangat mahal[12].

6) Dukungan kualitas. Komputer dapat meningkatkan kualitas keputusan yang dibuat, dengan kompuer para pengambil keputusan bisa melakukan simulasi yang kompleks, memeriksa banyak skenario yang memungkinkan dan menilai berbagai pengaruh secara cepat dan ekonomis[12].

7) Mampu bersaing. Persaingan yang ketat menyebabkan tugas manajemen menjadi tidak mudah dalam mengambil keputusan[12].

8) Mengatasi keterbatasan kognitif dalam pemrosesan dan penyimpanan[12].

Kriteria penilaian pada PT Tirta Jaya Abadi Singaraja dalam melakukan pemilihan pegawai terbaik menggunakan enam kriteriayaitu kesetiaan, prestasi kerja, tanggung jawab, ketaatan, kejujuran dan prakarsa. Penilaian ini dilakukan oleh pimpinan manajemen yang terdiri dari direktur, kabag. Jaminan mutu, kabag produksi, kabag pemasaran, dan kabag umum dan keuangan[13]. 
A. Tahapan dalam sistem pendukung keputusan[14], sebagai berikut:

1) Inteligence phase

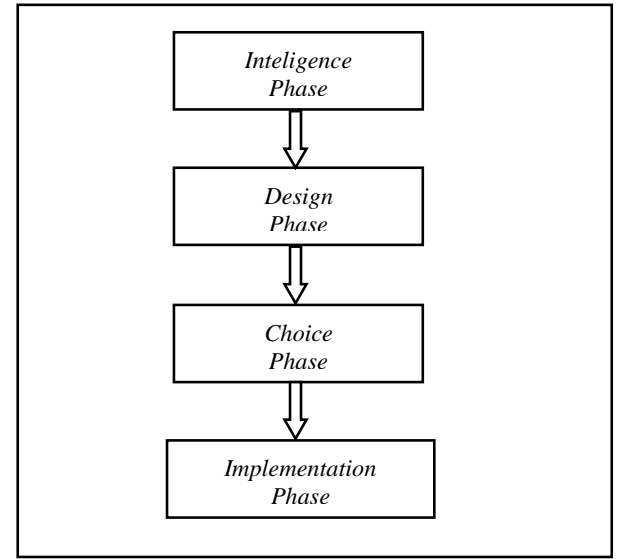

Gambar 1. Tahapan Sistem Pendukung Keputusan

Tahap pengidentifikasi masalah dengan memperoleh data masukan kemudian diproses serta diuji

2) Design phase

Merupakan proses pencarian alternatif untuk tindakan yang akan diambil. tahap perancangan ini sebagai representasi sehingga memerlukan proses validasi dan verifikasi untuk mengetahui keakuratan model terhadap permasalahan.

3) Choice phase

Melakukan pemilihan pada alternatif solusi yang dimunculkan berdasarkan kriteria-kriteria yang ditetapakan untuk tujuan yang akan dicapai

4) Implementation phase

Tahap penerapan dari perancangan dan pemilihan solusi yang telah dilakukan

B. Metode Simple Additive Weighting (SAW)

Metode SAW memerlukan proses normalisasi untuk matrik keputusan (X) pada skala yang diperbandingkan dari semua rating alteratif [15].

Langkah penyelesaian masalah menggunakan simple additive weighting, sebagai berikut:

1) Penentuan kriteria sebagai acuan pada pengambilan keputusan yaitu $(\mathrm{Cj})[15]$.

2) Pemberian nilai bobot pada setiap kriteria sebagai W[15].

3) Pemberian nilai kecocokan setiap alternatif pada kriteria[15].

4) Pembuatan matriks keputusan $\mathrm{Cj}$ untuk menghasilkan matriks ternormalisasi $\mathrm{R}$ berdasarkan proses normalisasi sesuai jenis atribut[15].

Keterangan:

$$
\mathrm{rij}=\left\{\begin{array}{l}
\frac{x i j}{M a x x i j} \mathrm{Jika} \mathrm{j} \text { adalah atribut keuntungan } \\
\frac{M i n x i j}{X i j} \mathrm{Jika} \mathrm{j} \text { adalah atribut biaya }
\end{array}\right.
$$

$\mathrm{r}_{\mathrm{ij}}=$ Nilai rating kinerja ternormalisasi[15]

$\mathrm{X}_{\mathrm{ij}}=$ Nilai atribut yang dimiliki dari setiap kriteria[15]

Max $X_{i j}=$ Nilai terbesar dari setiap kriteria[15]

Min $X_{\mathrm{ij}}=$ Nilai terkecil dari setiap kriteria[15]

Benefit $=$ Jika nilai terbesar adalah terbaik[15]

5) Hasil akhir diperoleh dari proses perankingan yaitu penjumlahan dan perkalian matriks ternormalisasi $R$ dengan vektor bobot sehingga diperoleh nilai terbesar yang dipilih sebagai alternative yang baik (Vi) sebagai solusi[15].

Keterangan:

$$
\mathrm{Vi}=\sum_{j=1}^{n} W j r i j
$$

$\mathrm{V}_{\mathrm{i}}=$ ranking untuk setiap alternatif[15]

$\mathrm{W}_{\mathrm{j}}=$ nilai bobot dari setiap kriteria[15]

$\mathrm{r}_{\mathrm{ij}}=$ nilai rating kinerja ternormalisasi $[15]$ 
JSAI : Journal Scientific and Applied Informatics

Vol. 3, No. 3, November 2020, hal. 95-105

E-ISSN: 2614-3054; P-ISSN: 2614-3062, accredited by Kemenristekdikti, Sinta 5

DOI: 10.36085

nilai $\mathrm{V}_{\mathrm{i}}$ yang lebih besar mengidentifikasikan bahwa alternatif $\mathrm{A}_{\mathrm{i}}$ lebih dipilih[15].

\section{METODE PENELITIAN}

Penelitian ini dilakukan pada PT. Cahaya Kasih Anugrah untuk mendapatkan karyawan terbaik yang berhak untuk mendapatkan reward dari perusahaan. Gambar 2 dibawah ini dijelaskan tahapan-tahapan yang dilakukan untuk pemberian reward kepada karyawan.

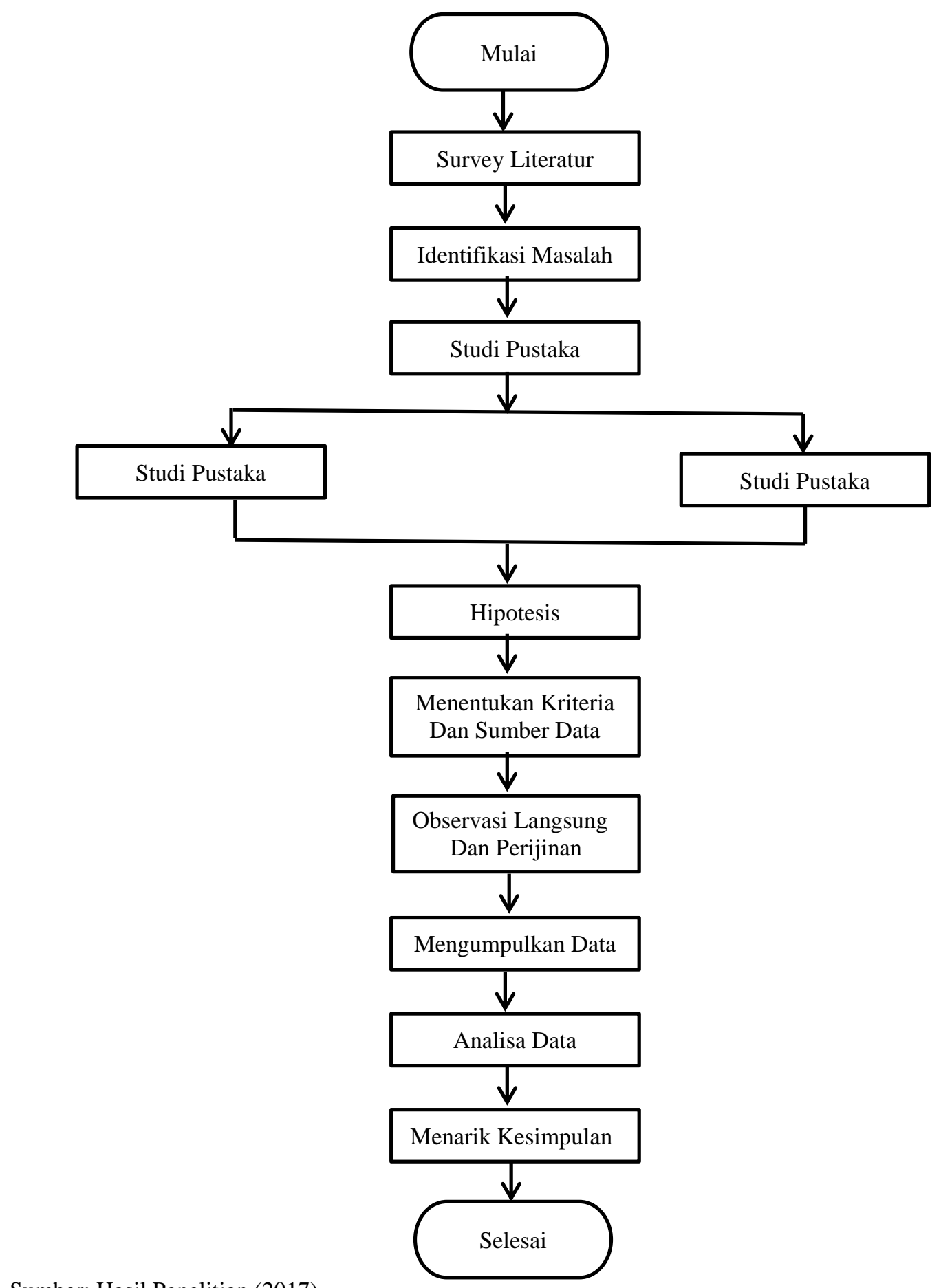

Sumber: Hasil Penelitian (2017)

Gambar 2. Tahapan Reward Kepada Karyawan

Penelitian ini dilakukan secara langsung pada perusahaan untuk mendapatkan data dan informasi yang dibutuhkan. Wawancara dengan mengajukan daftar pertanyaan dibutuhkan untuk melakukan pengumpulan data kepada pimpinan perusahaan diantara direktur, manajer, dan kepala personalia. 


\section{HASIL DAN ANALISIS}

Dalam analisa ini diperlukan beberapa kriteria dan bobot untuk melakukan perhitungan bobot. Hasilnya akan terlihat pada tabel 1 dibawah ini untuk menentukan karyawan yang mendapatkan reward.

Tabel 1. Kriteria dan Nilai Bobot

\begin{tabular}{lcc}
\hline \multicolumn{1}{c}{ Kriteria } & Skala & Preferensi \\
\hline Kopetensi & T & 0.25 \\
\hline Tanggung Jawab & C & 0.15 \\
\hline Cara Bersikap & SR & 0.10 \\
\hline Kerjasama & R & 0.15 \\
\hline Disiplin & ST & 0.35 \\
\hline
\end{tabular}

Sumber: Data Penelitian

Berdasarkan Tabel 1 tersebut dapat diidentifikasi kriteria sebagai berikut:

Kriteria Penilaian Kopetensi pada variabel C1 dn C2

C1 = Tingkatan pencapaian dalam bekerja selama setahun sesuai dengan harapan perusahaan.

C2 = Dapat mengerjakan suatu pekerjaan dengan teliti dan tepat sesuai yang diharapkan.

Kriteria Penilaian Tanggung Jawab pada variabel C3 dan C4

C3 = Dapat menyelesaikan pekerjaannya dengan baik.

C4 = Taat terhadap semua standaroperasional prosedur (SPO) yang ditetapkan dalam pekerjaan.

Kriteria penilaian Cara Bersikap

C5 = Menjalankan standar operasional prosedur yang ditetapkan pada perusahaan.

C6 = Menjalin komunikasi yan g baik dengan atasan maupun dengan bawahan .

Kriteria penilaian Kerjasama

C7 = Dapat bekerja sama dalam team.

C8 = Memiliki kreatifitas dalam menyelesaikan pekerjaan dengan hasil yang baik.

Kriteria penilaian Disiplin

C9 = Dapat bekerja sesuai dengan ruang lingkup struktur organisasi perusahaan.

$\mathrm{C} 10$ = Dapat dengan cepat menyesuaikan diri pada setiap keputusan-keputusan baru yang diambil perusahaan.

Berdasarkan hasil wawancara dengan pimpinan perusahaan yang terdiri dari Direktur, Manager dan Kepala Personalia didapatkan data pada tabel 3, tabel 4 dan tabel 5 sebagai berikut:

Tabel 3. Rating kecocokan oleh Direktur pada setiap kriteria

\begin{tabular}{|c|c|c|c|c|c|c|c|c|c|c|}
\hline Kode & \multicolumn{10}{|c|}{ Nilai Kriteria } \\
\hline Karyawan & $\mathrm{C} 1$ & $\mathrm{C} 2$ & $\mathrm{C} 3$ & $\mathrm{C} 4$ & $\mathrm{C} 5$ & C6 & $\mathrm{C7}$ & $\mathrm{C} 8$ & C9 & $\mathrm{C} 10$ \\
\hline $\mathrm{A} 1$ & 0.75 & 0.75 & 0.75 & 0.50 & 0.50 & 0.75 & 0.75 & 0.75 & 0.50 & 0.50 \\
\hline $\mathrm{A} 2$ & 1 & 0.75 & 0.75 & 0.75 & 0.50 & 0.50 & 0.75 & 0.75 & 0.50 & 0.50 \\
\hline A3 & 0.75 & 1 & 1 & 0.75 & 0.50 & 0.50 & 0.50 & 0.50 & 0.50 & 0.50 \\
\hline A4 & 0.75 & 0.75 & 0.75 & 1 & 0.50 & 0.75 & 0.50 & 0.75 & 0.50 & 0.50 \\
\hline A5 & 0.75 & 1 & 1 & 0.50 & 0.50 & 0.75 & 0.75 & 0.75 & 0.50 & 0.75 \\
\hline A6 & 1 & 1 & 0.75 & 0.75 & 0.75 & 0.75 & 0.50 & 0.50 & 0.50 & 0.50 \\
\hline A7 & 0.75 & 0.75 & 0.75 & 0.50 & 0.50 & 0.75 & 0.50 & 0.50 & 0.50 & 0.75 \\
\hline A8 & 0.75 & 0.75 & 1 & 0.50 & 0.50 & 0.75 & 0.75 & 0.75 & 0.25 & 0.50 \\
\hline A9 & 1 & 0.75 & 0.75 & 0.75 & 0.50 & 0.75 & 0.75 & 0.75 & 0.50 & 0.50 \\
\hline A10 & 0.75 & 0.75 & 0.75 & 0.50 & 0.75 & 0.75 & 1 & 1 & 0.75 & 0.50 \\
\hline A11 & 1 & 1 & 0.75 & 0.50 & 0.75 & 0.75 & 0.75 & 1 & 0.75 & 0.50 \\
\hline A12 & 0.50 & 0.75 & 0.75 & 0.50 & 0.75 & 0.50 & 0.75 & 1 & 0.75 & 0.75 \\
\hline A13 & 1 & 0.75 & 1 & 0.75 & 0.75 & 1 & 0.75 & 0.75 & 0.50 & 0.50 \\
\hline A14 & 0.50 & 0.75 & 0.75 & 0.50 & 0.50 & 1 & 1 & 0.50 & 0.50 & 0.50 \\
\hline A15 & 0.75 & 0.75 & 0.75 & 0.50 & 0.75 & 0.75 & 1 & 0.75 & 0.50 & 0.75 \\
\hline A16 & 1 & 0.75 & 0.75 & 0.75 & 0.75 & 0.75 & 0.50 & 0.50 & 0.75 & 0.75 \\
\hline A17 & 1 & 1 & 1 & 0.75 & 0.75 & 0.50 & 0.75 & 0.75 & 0.75 & 0.50 \\
\hline
\end{tabular}


JSAI : Journal Scientific and Applied Informatics

Vol. 3, No. 3, November 2020, hal. 95-105

E-ISSN: 2614-3054; P-ISSN: 2614-3062, accredited by Kemenristekdikti, Sinta 5

DOI: 10.36085

\begin{tabular}{lllllllllll}
\hline A18 & 0.75 & 0.75 & 0.75 & 0.50 & 0.50 & 0.50 & 0.75 & 0.75 & 0.25 & 0.50 \\
\hline
\end{tabular}

Berdasarkan rating kecocokan pada tabel 3 akan dibuat matrik keputusan sebagai berikut:

$\mathrm{X}=\left[\begin{array}{cccccccccc}0.75 & 0.75 & 0.75 & 0.50 & 0.50 & 0.75 & 0.75 & 0.75 & 0.50 & 0.50 \\ 1 & 0.75 & 0.75 & 0.75 & 0.50 & 0.50 & 0.75 & 0.75 & 0.50 & 0.50 \\ 0.75 & 1 & 1 & 0.75 & 0.50 & 0.50 & 0.50 & 0.50 & 0.50 & 0.50 \\ 0.75 & 0.75 & 0.75 & 1 & 0.50 & 0.75 & 0.50 & 0.75 & 0.50 & 0.50 \\ 0.75 & 1 & 1 & 0.50 & 0.50 & 0.75 & 0.75 & 0.75 & 0.50 & 0.75 \\ 1 & 1 & 0.75 & 0.75 & 0.75 & 0.75 & 0.50 & 0.50 & 0.50 & 0.50 \\ 0.75 & 0.75 & 0.75 & 0.50 & 0.50 & 0.75 & 0.50 & 0.50 & 0.50 & 0.75 \\ 0.75 & 0.75 & 1 & 0.50 & 0.75 & 0.75 & 0.75 & 0.50 & 0.25 & 0.50 \\ 1 & 0.75 & 0.75 & 0.75 & 0.50 & 0.50 & 0.75 & 0.75 & 0.50 & 0.50 \\ 0.75 & 0.75 & 1 & 0.50 & 0.75 & 0.75 & 0.75 & 0.75 & 0.25 & 0.50 \\ 1 & 1 & 0.75 & 0.50 & 0.75 & 0.75 & 0.75 & 1 & 0.75 & 0.50 \\ 0.50 & 0.75 & 0.75 & 0.50 & 0.75 & 0.50 & 0.75 & 1 & 0.75 & 0.75 \\ 1 & 0.75 & 1 & 0.75 & 0.75 & 1 & 0.75 & 0.75 & 0.50 & 0.50 \\ 0.50 & 0.75 & 0.75 & 0.50 & 0.50 & 1 & 1 & 0.50 & 0.50 & 0.50 \\ 0.75 & 0.75 & 0.75 & 0.50 & 0.75 & 0.75 & 1 & 0.75 & 0.50 & 0.75 \\ 1 & 0.75 & 0.75 & 0.75 & 0.75 & 0.75 & 0.50 & 0.50 & 0.75 & 0.75 \\ 1 & 1 & 1 & 0.75 & 0.75 & 0.50 & 0.75 & 0.75 & 0.75 & 0.50 \\ 0.75 & 0.75 & 0.75 & 0.50 & 0.50 & 0.50 & 0.75 & 0.75 & 0.25 & 0.50\end{array}\right]$

Sumber: Hasil Penelitian

Nilai(X) adalah hasil konversi fuzzy ke crips, nilai $(\mathrm{R})$ adalah proses normalisasi ke skala perbandingan untuk semua rating alternatif dalam mencari nilai benefit. Hasil matrik R sebagai berikut:

$\mathrm{R}=\left[\begin{array}{cccccccccc}0.75 & 0.75 & 0.75 & 0.50 & 0.67 & 0.75 & 0.75 & 0.75 & 0.67 & 0.67 \\ 1 & 0.75 & 0.75 & 0.75 & 0.67 & 0.50 & 0.75 & 0.75 & 0.67 & 0.67 \\ 0.75 & 1 & 1 & 0.75 & 0.67 & 0.50 & 0.50 & 0.50 & 0.67 & 0.67 \\ 0.75 & 0.75 & 0.75 & 1 & 0.67 & 0.75 & 0.50 & 0.75 & 0.67 & 0.67 \\ 0.75 & 1 & 1 & 0.50 & 0.67 & 0.75 & 0.75 & 0.75 & 0.67 & 1 \\ 1 & 1 & 0.75 & 0.75 & 1 & 0.75 & 0.50 & 0.50 & 0.67 & 0.67 \\ 0.75 & 0.75 & 0.75 & 0.50 & 0.67 & 0.75 & 0.50 & 0.50 & 0.67 & 1 \\ 0.75 & 0.75 & 1 & 0.50 & 1 & 0.75 & 0.75 & 0.75 & 0.33 & 0.67 \\ 1 & 0.75 & 0.75 & 0.75 & 0.67 & 0.50 & 0.75 & 0.75 & 0.67 & 0.67 \\ 0.75 & 0.75 & 0.75 & 0.50 & 1 & 0.75 & 1 & 1 & 1 & 0.67 \\ 1 & 1 & 0.75 & 0.50 & 1 & 0.75 & 0.75 & 1 & 1 & 0.67 \\ 0.50 & 0.75 & 0.75 & 0.50 & 1 & 0.50 & 0.75 & 1 & 1 & 1 \\ 1 & 0.75 & 1 & 0.75 & 1 & 1 & 0.75 & 0.75 & 0.67 & 0.67 \\ 0.50 & 0.75 & 0.75 & 0.50 & 0.67 & 1 & 1 & 0.50 & 0.67 & 0.67 \\ 0.75 & 0.75 & 0.75 & 0.50 & 1 & 0.75 & 1 & 0.75 & 0.67 & 1 \\ 1 & 0.75 & 0.75 & 0.75 & 1 & 0.75 & 0.50 & 0.50 & 1 & 1 \\ 1 & 1 & 1 & 0.75 & 1 & 0.50 & 0.75 & 0.75 & 1 & 0.67 \\ 0.75 & 0.75 & 0.75 & 0.50 & 0.67 & 0.50 & 0.75 & 0.75 & 0.33 & 0.67\end{array}\right]$

Sumber: Hasil Penelitian

Hasil (V) matrik keputusan oleh direktur sebagai berikut:

$$
V=\left[\begin{array}{l}
1.38 \\
1.46 \\
1.37 \\
1.42 \\
1.51 \\
1.45 \\
1.29 \\
1.33 \\
1.46 \\
1.65 \\
1.74 \\
1.56 \\
1.58 \\
1.29 \\
1.48 \\
1.54 \\
1.70 \\
1.24
\end{array}\right]
$$


JSAI : Journal Scientific and Applied Informatics

Vol. 3, No. 3, November 2020, hal. 95-105

E-ISSN: 2614-3054; P-ISSN: 2614-3062, accredited by Kemenristekdikti, Sinta 5

DOI: 10.36085

Tabel 4. Rating kecocokan oleh Manager pada setiap kriteria

\begin{tabular}{|c|c|c|c|c|c|c|c|c|c|c|}
\hline \multirow{2}{*}{$\frac{\text { Kode }}{\text { Karyawan }}$} & \multicolumn{10}{|c|}{ Nilai Kriteria } \\
\hline & $\mathrm{C} 1$ & $\mathrm{C} 2$ & C3 & $\mathrm{C} 4$ & $\mathrm{C} 5$ & C6 & C7 & $\mathrm{C} 8$ & C9 & $\mathrm{C} 10$ \\
\hline A1 & 0.50 & 0.50 & 0.50 & 0.25 & 0.50 & 0.75 & 0.50 & 0.75 & 0.50 & 0.75 \\
\hline $\mathrm{A} 2$ & 0.50 & 0.75 & 0.75 & 0.50 & 0.50 & 0.50 & 0.75 & 0.50 & 0.50 & 0.25 \\
\hline A3 & 0.75 & 0.50 & 0.50 & 0.25 & 0.25 & 0.50 & 0.50 & 0.50 & 0.50 & 0.50 \\
\hline A4 & 0.75 & 0.50 & 0.50 & 0.25 & 0.50 & 0.75 & 0.50 & 0.75 & 0.50 & 0.25 \\
\hline A5 & 0.75 & 0.50 & 0.50 & 0.75 & 0.50 & 0.75 & 0.75 & 0.50 & 0.50 & 0.50 \\
\hline A6 & 0.50 & 0.50 & 0.50 & 0.50 & 0.75 & 0.50 & 0.50 & 0.25 & 0.50 & 0.25 \\
\hline A7 & 0.50 & 0.75 & 0.50 & 0.50 & 0.50 & 0.75 & 0.50 & 0.50 & 0.50 & 0.75 \\
\hline A8 & 0.25 & 0.75 & 0.50 & 0.25 & 0.25 & 0.50 & 0.50 & 0.25 & 0.50 & 0.25 \\
\hline A9 & 1 & 1 & 0.75 & 0.50 & 0.75 & 1 & 0.75 & 0.75 & 0.25 & 0.50 \\
\hline A10 & 0.75 & 0.50 & 0.50 & 0.25 & 0.25 & 0.75 & 0.50 & 0.50 & 0.75 & 0.25 \\
\hline A11 & 1 & 0.75 & 0.75 & 0.50 & 0.50 & 0.75 & 0.50 & 1 & 0.50 & 0.25 \\
\hline A12 & 0.50 & 0.75 & 0.75 & 0.50 & 0.25 & 0.50 & 0.50 & 1 & 0.50 & 0.25 \\
\hline A13 & 0.50 & 0.50 & 0.50 & 0.75 & 0.75 & 0.50 & 0.50 & 0.50 & 0.50 & 0.25 \\
\hline A14 & 0.50 & 0.25 & 0.50 & 0.50 & 0.25 & 0.50 & 1 & 0.50 & 0.50 & 0.50 \\
\hline A15 & 0.50 & 0.75 & 0.50 & 0.50 & 0.75 & 0.50 & 0.75 & 0.75 & 0.50 & 0.50 \\
\hline A16 & 0.75 & 0.75 & 0.50 & 0.50 & 0.75 & 0.75 & 0.50 & 0.50 & 0.50 & 0.75 \\
\hline A17 & 0.50 & 0.75 & 0.50 & 0.50 & 0.75 & 0.75 & 0.50 & 0.50 & 0.50 & 0.25 \\
\hline A18 & 0.50 & 0.75 & 0.50 & 0.50 & 0.25 & 0.50 & 0.75 & 0.50 & 0.25 & 0.25 \\
\hline
\end{tabular}

Berdasarkan rating kecocokan pada tabel 4 akan dibuat matrik keputusan sebagai berikut:

$X=\left[\begin{array}{cccccccccc}0.50 & 0.50 & 0.50 & 0.25 & 0.50 & 0.75 & 0.50 & 0.75 & 0.50 & 0.75 \\ 0.50 & 0.75 & 0.75 & 0.50 & 0.50 & 0.50 & 0.75 & 0.50 & 0.50 & 0.25 \\ 0.75 & 0.75 & 0.50 & 0.25 & 0.25 & 0.50 & 0.50 & 0.50 & 0.50 & 0.50 \\ 0.75 & 0.50 & 0.50 & 0.25 & 0.50 & 0.75 & 0.50 & 0.75 & 0.50 & 0.25 \\ 0.75 & 0.50 & 0.50 & 0.75 & 0.50 & 0.75 & 0.75 & 0.50 & 0.50 & 0.50 \\ 0.50 & 0.50 & 0.50 & 0.50 & 0.75 & 0.50 & 0.50 & 0.25 & 0.50 & 0.25 \\ 0.50 & 0.75 & 0.50 & 0.50 & 0.50 & 0.75 & 0.50 & 0.50 & 0.50 & 0.75 \\ 0.25 & 0.75 & 0.50 & 0.25 & 0.25 & 0.50 & 0.50 & 0.25 & 0.50 & 0.25 \\ 1 & 1 & 0.75 & 0.50 & 0.75 & 1 & 0.75 & 0.75 & 0.25 & 0.50 \\ 0.75 & 0.50 & 0.50 & 0.25 & 0.25 & 0.75 & 0.50 & 0.50 & 0.75 & 0.25 \\ 1 & 0.75 & 0.75 & 0.50 & 0.50 & 0.75 & 0.50 & 1 & 0.50 & 0.25 \\ 0.50 & 0.75 & 0.75 & 0.50 & 0.25 & 0.50 & 0.50 & 1 & 0.50 & 0.25 \\ 0.50 & 0.50 & 0.50 & 0.75 & 0.75 & 0.50 & 0.50 & 0.50 & 0.50 & 0.25 \\ 0.50 & 0.25 & 0.50 & 0.50 & 0.25 & 0.50 & 1 & 0.50 & 0.50 & 0.50 \\ 0.50 & 0.75 & 0.50 & 0.50 & 0.75 & 0.50 & 0.75 & 0.75 & 0.50 & 0.50 \\ 0.75 & 0.75 & 0.50 & 0.50 & 0.75 & 0.75 & 0.50 & 0.50 & 0.50 & 0.75 \\ 0.50 & 0.25 & 0.50 & 0.50 & 0.25 & 0.50 & 0.50 & 0.50 & 0.50 & 0.25 \\ 0.50 & 0.75 & 0.50 & 0.50 & 0.25 & 0.50 & 0.75 & 0.50 & 0.25 & 0.25\end{array}\right]$

Sumber: Hasil Penelitian

Nilai(X) adalah hasil konversi fuzzy ke crips, nilai (R) adalah proses normalisasi ke skala perbandingan untuk semua rating alternatif dalam mencari nilai benefit. Hasil matrik R sebagai berikut

$R=\left[\begin{array}{llllllllll}0.50 & 0.50 & 0.67 & 0.33 & 0.67 & 0.75 & 0.50 & 0.75 & 0.67 & 1.00 \\ 0.50 & 0.75 & 1.00 & 0.67 & 0.67 & 0.50 & 0.75 & 0.50 & 0.67 & 0.33 \\ 0.75 & 0.50 & 0.67 & 0.33 & 0.33 & 0.50 & 0.50 & 0.50 & 0.67 & 0.67 \\ 0.75 & 0.50 & 0.67 & 0.33 & 0.67 & 0.75 & 0.50 & 0.75 & 0.67 & 0.33 \\ 0.75 & 0.50 & 0.67 & 1.00 & 0.67 & 0.75 & 0.75 & 0.50 & 0.67 & 0.67 \\ 0.50 & 0.50 & 0.67 & 0.67 & 1.00 & 0.50 & 0.50 & 0.25 & 0.67 & 0.33 \\ 0.50 & 0.75 & 0.67 & 0.67 & 0.67 & 0.75 & 0.50 & 0.50 & 0.67 & 1.00 \\ 0.25 & 0.75 & 0.67 & 0.33 & 0.33 & 0.50 & 0.50 & 0.25 & 0.67 & 0.33 \\ 1.00 & 1.00 & 1.00 & 0.67 & 1.00 & 1.00 & 0.75 & 0.75 & 0.33 & 0.67 \\ 0.75 & 0.50 & 1.00 & 0.33 & 0.33 & 0.75 & 0.50 & 0.50 & 0.75 & 0.33 \\ 1.00 & 0.75 & 1.00 & 0.67 & 0.67 & 0.5 & 0.50 & 1.00 & 0.67 & 0.33 \\ 0.50 & 0.75 & 1.00 & 0.67 & 0.33 & 0.50 & 0.50 & 1.00 & 0.67 & 0.33 \\ 0.50 & 0.50 & 0.67 & 1.00 & 1.00 & 0.50 & 0.50 & 0.50 & 0.67 & 0.33 \\ 0.50 & 0.25 & 0.67 & 0.67 & 0.33 & 0.50 & 1.00 & 0.50 & 0.67 & 0.67 \\ 0.50 & 0.75 & 0.67 & 0.67 & 1.00 & 0.50 & 0.75 & 0.75 & 0.67 & 0.67 \\ 0.75 & 0.75 & 0.67 & 0.67 & 1.00 & 0.75 & 0.50 & 0.50 & 0.67 & 1.00 \\ 0.50 & 0.25 & 0.67 & 0.67 & 0.33 & 0.50 & 0.50 & 0.50 & 0.67 & 0.33 \\ 0.50 & 0.75 & 0.67 & 0.67 & 0.33 & 0.50 & 0.75 & 0.50 & 0.33 & 0.33\end{array}\right]$

Sumber: Hasil Penelitian 
JSAI : Journal Scientific and Applied Informatics

Vol. 3, No. 3, November 2020, hal. 95-105

E-ISSN: 2614-3054; P-ISSN: 2614-3062, accredited by Kemenristekdikti, Sinta 5

DOI: 10.36085

Hasil (V) matrik keputusan oleh manajer sebagai berikut:

Hasil (V) Matriks Keputusan oleh Manajer

$$
V=\left[\begin{array}{l}
1.31 \\
1.22 \\
1.16 \\
1.14 \\
1.36 \\
1.06 \\
1.39 \\
0.95 \\
1.53 \\
1.15 \\
1.40 \\
1.22 \\
1.15 \\
1.16 \\
1.35 \\
1.48 \\
0.97 \\
1.02
\end{array}\right]
$$

Tabel 5. Rating kecocokan oleh Personalia pada setiap kriteria

\begin{tabular}{ccccccccccc}
\hline Kode & & \multicolumn{1}{c}{ Nilai Kriteria } & & & & C \\
\hline $\begin{array}{c}\text { Karyawan } \\
\text { Alternatif }\end{array}$ & $\mathrm{C} 1$ & $\mathrm{C} 2$ & $\mathrm{C} 3$ & $\mathrm{C} 4$ & $\mathrm{C} 5$ & $\mathrm{C} 6$ & $\mathrm{C} 7$ & $\mathrm{C} 8$ & $\mathrm{C} 9$ & $\mathrm{C} 10$ \\
\hline $\mathrm{A} 1$ & 0.75 & 1 & 1 & 0.75 & 0.50 & 0.75 & 0.75 & 0.75 & 0.75 & 0.50 \\
\hline $\mathrm{A} 2$ & 1 & 1 & 1 & 0.75 & 0.75 & 0.75 & 0.75 & 1 & 0.75 & 1 \\
\hline $\mathrm{A} 3$ & 0.75 & 0.50 & 1 & 0.75 & 1 & 0.75 & 0.75 & 0.50 & 0.75 & 0.75 \\
\hline A4 & 0.75 & 1 & 0.75 & 1 & 1 & 0.50 & 0.50 & 0.50 & 0.75 & 0.75 \\
\hline A5 & 0.75 & 0.75 & 0.75 & 1 & 1 & 1 & 1 & 0.75 & 0.50 & 0.75 \\
\hline A6 & 0.75 & 0.75 & 0.75 & 0.50 & 0.50 & 0.50 & 0.50 & 0.50 & 0.50 & 0.75 \\
\hline A7 & 0.50 & 0.50 & 1 & 0.50 & 0.50 & 0.50 & 0.75 & 0.50 & 0.50 & 0.50 \\
\hline A8 & 0.75 & 1 & 0.75 & 0.50 & 0.50 & 0.50 & 0.75 & 0.50 & 0.75 & 0.75 \\
\hline A9 & 0.75 & 0.75 & 0.75 & 0.75 & 0.75 & 0.75 & 1 & 1 & 0.75 & 0.75 \\
\hline A10 & 0.50 & 0.75 & 0.75 & 0.75 & 0.50 & 0.50 & 0.25 & 0.50 & 0.75 & 0.75 \\
\hline A11 & 0.75 & 0.75 & 1 & 0.75 & 0.50 & 0.25 & 0.25 & 0.50 & 0.75 & 0.75 \\
\hline A12 & 0.75 & 0.75 & 0.75 & 1 & 0.50 & 0.50 & 0.75 & 0.75 & 0.75 & 0.75 \\
\hline A13 & 0.50 & 0.50 & 0.75 & 0.50 & 0.50 & 0.50 & 0.75 & 0.75 & 0.75 & 0.75 \\
\hline A14 & 0.50 & 0.75 & 0.75 & 1 & 0.75 & 1 & 1 & 1 & 0.75 & 0.75 \\
\hline A15 & 0.75 & 0.75 & 1 & 1 & 1 & 0.75 & 0.75 & 0.75 & 1 & 0.75 \\
\hline A16 & 0.50 & 0.75 & 0.75 & 0.75 & 0.50 & 0.50 & 0.50 & 0.25 & 0.75 & 0.75 \\
\hline A17 & 0.75 & 1 & 1 & 0.75 & 0.25 & 0.50 & 0.75 & 0.75 & 1 & 1 \\
\hline A18 & 0.50 & 0.50 & 0.50 & 0.75 & 0.75 & 0.50 & 0.50 & 0.75 & 1 & 1 \\
\hline
\end{tabular}

Sumber: Hasil Penelitian

Berdasarkan rating kecocokan pada tabel 5 akan dibuat matrik keputusan sebagai berikut: 
JSAI : Journal Scientific and Applied Informatics

Vol. 3, No. 3, November 2020, hal. 95-105

E-ISSN: 2614-3054; P-ISSN: 2614-3062, accredited by Kemenristekdikti, Sinta 5

DOI: 10.36085

$\mathrm{X}=\left[\begin{array}{cccccccccc}0.75 & 1 & 1 & 0.75 & 0.50 & 0.75 & 0.75 & 0.75 & 0.75 & 0.50 \\ 1 & 1 & 1 & 0.75 & 0.75 & 0.75 & 0.75 & 1 & 0.75 & 1 \\ 0.75 & 0.50 & 1 & 0.75 & 1 & 0.75 & 0.75 & 0.50 & 0.75 & 0.75 \\ 0.75 & 1 & 0.75 & 1 & 1 & 0.50 & 0.50 & 0.50 & 0.75 & 0.75 \\ 0.75 & 0.75 & 0.75 & 1 & 1 & 1 & 1 & 0.75 & 0.50 & 0.75 \\ 0.75 & 0.75 & 0.75 & 0.50 & 0.50 & 0.50 & 0.50 & 0.50 & 0.50 & 0.75 \\ 0.50 & 0.50 & 1 & 0.50 & 0.50 & 0.50 & 0.75 & 0.50 & 0.50 & 0.50 \\ 0.75 & 1 & 0.75 & 0.50 & 0.50 & 0.50 & 0.75 & 0.50 & 0.75 & 0.75 \\ 0.75 & 0.75 & 0.75 & 0.75 & 0.75 & 0.75 & 1 & 1 & 0.75 & 0.75 \\ 0.50 & 0.75 & 0.75 & 0.75 & 0.50 & 0.50 & 0.25 & 0.50 & 0.75 & 0.75 \\ 0.75 & 0.75 & 1 & 0.75 & 0.50 & 0.25 & 0.25 & 0.50 & 0.75 & 0.75 \\ 0.75 & 0.75 & 0.75 & 1 & 0.50 & 0.50 & 0.75 & 0.75 & 0.75 & 0.75 \\ 0.50 & 1 & 0.75 & 0.50 & 0.50 & 0.50 & 0.75 & 0.75 & 0.75 & 0.75 \\ 0.50 & 0.75 & 0.75 & 1 & 0.75 & 1 & 1 & 1 & 0.75 & 0.75 \\ 0.75 & 0.75 & 1 & 1 & 1 & 0.75 & 0.75 & 0.75 & 1 & 0.75 \\ 0.50 & 0.75 & 0.75 & 0.75 & 0.50 & 0.50 & 0.50 & 0.25 & 0.75 & 0.75 \\ 0.75 & 1 & 1 & 0.75 & 0.25 & 0.50 & 0.75 & 0.75 & 1 & 1 \\ 0.50 & 0.50 & 0.50 & 0.75 & 0.75 & 0.50 & 0.50 & 0.75 & 1 & 1\end{array}\right]$

Sumber: Hasil Penelitian

Nilai(X) adalah hasil konversi fuzzy ke crips, nilai (R) adalah proses normalisasi ke skala perbandingan untuk semua rating alternatif dalam mencari nilai benefit. Hasil matrik R sebagai berikut

$\mathrm{R}=\left[\begin{array}{llllllllll}0.75 & 1.00 & 1.00 & 0.75 & 0.50 & 0.75 & 0.75 & 0.75 & 0.75 & 0.50 \\ 1.00 & 1.00 & 1.00 & 0.75 & 0.75 & 0.75 & 0.75 & 1.00 & 0.75 & 1.00 \\ 0.75 & 0.50 & 1.00 & 0.75 & 1.00 & 0.75 & 0.75 & 0.50 & 0.75 & 0.75 \\ 0.75 & 1.00 & 0.75 & 1.00 & 1.00 & 0.50 & 0.50 & 0.50 & 0.75 & 0.75 \\ 0.75 & 0.75 & 0.75 & 1.00 & 1.00 & 1.00 & 1.00 & 0.75 & 0.50 & 0.75 \\ 0.75 & 0.75 & 0.75 & 0.50 & 0.50 & 0.50 & 0.50 & 0.50 & 0.50 & 0.75 \\ 0.50 & 0.50 & 1.00 & 0.50 & 0.50 & 0.50 & 0.75 & 0.50 & 0.50 & 0.50 \\ 0.75 & 1.00 & 0.75 & 0.50 & 0.50 & 0.50 & 0.75 & 0.50 & 0.75 & 0.75 \\ 0.75 & 0.75 & 0.75 & 0.75 & 0.75 & 0.75 & 1.00 & 1.00 & 0.75 & 0.75 \\ 0.50 & 0.75 & 0.75 & 0.75 & 0.50 & 0.50 & 0.25 & 0.50 & 0.75 & 0.75 \\ 0.75 & 0.75 & 1.00 & 0.75 & 0.50 & 0.25 & 0.25 & 0.50 & 0.75 & 0.75 \\ 0.75 & 0.75 & 0.75 & 1.00 & 0.50 & 0.50 & 0.75 & 0.75 & 0.75 & 0.75 \\ 0.50 & 0.50 & 0.75 & 0.50 & 0.50 & 0.50 & 0.75 & 0.75 & 0.75 & 0.75 \\ 0.50 & 0.75 & 0.75 & 1.00 & 0.75 & 1.00 & 1.00 & 1.00 & 0.75 & 0.75 \\ 0.75 & 0.75 & 1.00 & 1.00 & 1.00 & 0.75 & 0.75 & 0.75 & 1.00 & 0.75 \\ 0.50 & 0.75 & 0.75 & 0.75 & 0.50 & 0.50 & 0.50 & 0.25 & 0.75 & 0.75 \\ 0.75 & 1.00 & 1.00 & 0.75 & 0.25 & 0.50 & 0.75 & 0.75 & 1.00 & 1.00 \\ 0.50 & 0.50 & 0.50 & 0.75 & 0.75 & 0.50 & 0.50 & 0.75 & 1.00 & 1.00\end{array}\right]$

Sumber: Hasil Penelitian

Hasil (V) matrik keputusan oleh personalia sebagai berikut: 
JSAI : Journal Scientific and Applied Informatics

Vol. 3, No. 3, November 2020, hal. 95-105

E-ISSN: 2614-3054; P-ISSN: 2614-3062, accredited by Kemenristekdikti, Sinta 5

DOI: 10.36085

$$
\mathrm{V}=\left[\begin{array}{l}
1.49 \\
1.79 \\
1.46 \\
1.53 \\
1.54 \\
1.25 \\
1.11 \\
1.44 \\
1.58 \\
1.28 \\
1.35 \\
1.49 \\
1.29 \\
1.58 \\
1.69 \\
1.28 \\
1.70 \\
1.45
\end{array}\right]
$$

Melakukan Perangkingan

Perangkingan dilakukan setelah melakukan proses normalisasi dari rating kecocokan yang dilakukan oleh direktur, manajer dan personalia dengan menjumlahkan nilai vektor pada tabel 6 dibawah ini.

Tabel 6. Hasil Perangkingan Karyawan

\begin{tabular}{|c|c|c|c|c|c|c|}
\hline Alternatif & Nama & Direktur & Manager & Personalia & Jumlah & Rangking \\
\hline A9 & Fredy & 1.46 & 1.53 & 1.58 & 4.57 & 1 \\
\hline A15 & Suyono & 1.48 & 1.35 & 1.69 & 4.52 & 2 \\
\hline A11 & Yusuf M & 1.74 & 1.4 & 1.35 & 4.49 & 3 \\
\hline A2 & Agusman & 1.46 & 1.22 & 1.79 & 4.47 & 4 \\
\hline A5 & Ronald & 1.51 & 1.36 & 1.54 & 4.41 & 5 \\
\hline A17 & Wahyu P & 1.7 & 0.97 & 1.7 & 4.37 & 6 \\
\hline A16 & Legiman & 1.54 & 1.48 & 1.28 & 4.3 & 7 \\
\hline A12 & Juventus & 1.56 & 1.22 & 1.49 & 4.27 & 8 \\
\hline A1 & Budi S & 1.38 & 1.31 & 1.49 & 4.18 & 9 \\
\hline A4 & Rio & 1.42 & 1.14 & 1.53 & 4.09 & 10 \\
\hline A10 & Winarno & 1.65 & 1.15 & 1.28 & 4.08 & 11 \\
\hline A14 & Revando & 1.29 & 1.16 & 1.58 & 4.03 & 12 \\
\hline A13 & Sarmun & 1.58 & 1.15 & 1.29 & 4.02 & 13 \\
\hline A3 & Suyitno & 1.37 & 1.16 & 1.46 & 3.99 & 14 \\
\hline A7 & Akim & 1.29 & 1.39 & 1.11 & 3.79 & 15 \\
\hline A6 & Chika & 1.45 & 1.06 & 1.25 & 3.76 & 16 \\
\hline A8 & Nasir & 1.33 & 0.95 & 1.44 & 3.72 & 17 \\
\hline A18 & Bambang & 1.24 & 1.02 & 1.45 & 3.71 & 18 \\
\hline
\end{tabular}

\section{KESIMPULAN}

Kesimpulan dari penelitian ini didapakan karyawan terbaik untuk mendapatkan reward dari perusahaan adalah saudara fredy setelah dilakukan penjumlahan nilai preferensi dari pimpinan perusahaan yang masingmasing didapatkan nilai preferensi 1.46, 1.53 dan 1.58 dengan total nilai sebesar 4.57. penilaian ini dengan mengikuti kriteria-kriteria yang ditetapkan perusahaan untuk seluruh karyawannya.

Penelitian ini masih ada kekurangan dalam keterbatasan variabel yang digunakan sehingga diharapkan kriteria penilaian yang sudah ada dapat ditambahkan agar menjadi lebih baik lagi.

Kedepannya perlu dibuatkan sebuah sistem aplikasi untuk penilaian karyawan terbaik ini berdasarkan kriteria penilaian yang telah ditetapkan sehingga menghasilkan informasi keputusan yang baik dan cepat.

\section{REFERENSI}

[1] H. Murdianto, D. M. Khairina, and H. R. Hatta, "SISTEM PENDUKUNG KEPUTUSAN PEMILIHAN KARYAWAN TERBAIK PER TRIWULAN PT . CAHAYA FAJAR KALTIM PLTU EMBALUT TANJUNG BATU MENGGUNAKAN METODE SIMPLE ADDITIVE WEIGHTING," vol. 1, no. 1, pp. 24-29, 2016.

[2] T. N. Saragih, "Sistem Pendukung Keputusan Pemberian Reward Kepada Karyawan Menggunakan Metode Preference Selection Index," pp. 615-622, 2019.

[3] A. Triwahyuni, "Sistem Pendukung Keputusan Penentuan Karyawan Terbaik Carrefour 
Menggunakan Metode Simple Additive Weighting (Saw)," J. Inform. Darmajaya, vol. 15, no. 1, pp. 66-80, 2015.

[4] A. M. Dawis, "Sistem Pendukung Keputusan Pemberian Reward Pegawai Menggunakan Metode TOPSIS," no. 1, pp. 11-24, 2020.

[5] M. R. Maulana, K. Kunci, : Sistem, P. Keputusan, and P. K. Karyawan, "PENILAIAN KINERJA KARYAWAN DI IFUN JAYA TEXTILE DENGAN METODE FUZZY SIMPLE ADDITIVE WEIGHTED," J. Ilm. ICTech, no. 1, 2012.

[6] R. Taufiq, C. A. Saputra, U. M. Tangerang, and J. P. I. Cikokol-tangerang, "Perancangan Sistem Pendukung Keputusan Penilaian Kinerja Guru Menggunakan Metode Saw Pada Sman 15 Tangerang," vol. 07, pp. 75-80, 2018.

[7] A. Suryana, E. Yulianto, and K. D. Pratama, "PERANCANGAN SISTEM PENDUKUNG KEPUTUSAN PENILAIAN PRESTASI PEGAWAI MENGGUNAKAN METODE SAW, AHP, DAN TOPSIS Ase," J. Ilm. Teknol. Inf. Terap., vol. 3, no. 2, pp. 130-139, 2017.

[8] P. P. T. Abc, "Penggunaan Metode Simple Additive Weighting ( SAW ) dalam Pengambilan Keputusan Rekrutmen Karyawan,” vol. 19, no. 1, pp. 45-55, 2020.

[9] D. Nofriansyah, Konsep Data Mining vs Sistem Pendukung Keputusan. Yogyakarta: Deepublish, 2015.

[10] M. Masri, "Penentuan Karyawan Terbaik Dengan Metode Simple Additive Weighting (PDAM Tirta Silaupiasa)," JET (Journal Electr. Technol., vol. 1, no. 1, pp. 36-41, 2016.

[11] M. R. Maulana, K. Kunci, : Sistem, P. Keputusan, and P. K. Karyawan, "PENILAIAN KINERJA KARYAWAN DI IFUN JAYA TEXTILE DENGAN METODE FUZZY SIMPLE ADDITIVE WEIGHTED," J. Ilm. ICTech, no. 1, 2012.

[12] Kusrini, Konsep dan Apliksai Sistem Pendukung Keputusan. Yogyakarta: Andi Offset \& Amikom, 2007.

[13] S. I Gede, W. I Made.A, and S. I Made.G, "Pengembangan Sistem Pendukung Keputusan Pemilihan Pegawai Terbaik Menggunakan Metode Simple Additive Weighting ( Saw ) Di Pt Tirta Jaya Abadi Singaraja," Kumpul. Artik. Mhs. Pendidik. Tek. Inform., vol. 4, no. 5, pp. 164-170, 2015.

[14] M. M. Saw, "IMPLEMENTASI SISTEM KEPUTUSAN PENGANGKATAN KARYAWAN TETAP PT . IMANUEL SURYA UTAMA,” vol. 2, no. 1, 2015.

[15] M. F. Penta, F. B. Siahaan, and S. H. Sukamana, "Sistem Pendukung Keputusan Pemilihan Karyawan Terbaik Menggunakan Metode SAW pada PT. Kujang Sakti Anugrah,” JSAI (Journal Sci. Appl. Informatics), vol. 2, no. 3, pp. 185-192, 2019. 